\title{
QUALITY MANAGEMENT SYSTEMS IN LOGISTICS
}

\author{
Audrius Gargasas ${ }^{1}$, Mindaugas Samuolaitis² ${ }^{2}$ Indra Mūgienè ${ }^{3}$ \\ ${ }^{1}$ Prof. Dr. Vytautas Magnus University. Universiteto g. 10. LT-53361 Akademija, \\ Kauno r.Tel.(8610)37883.E-mail audrius.gargasas@vdu.lt \\ ${ }^{2}$ Asist.Vytautas Magnus University.E-mail mindaugas.samuolaitis@vdu.lt \\ ${ }^{3}$ Lect.Vytautas Magnus University.E-mail indra.mugiene@vdu.lt
}

Received 0515 2019; accepted 30062019

Service quality is one of the most important aspects of enhancing the competitiveness of enterprises. Logistics companies are implementing quality management systems in order to ensure the quality of the services. Whereas logistics companies carry out different activities, there is a risk that application of inadequate quality management system would result in financial losses. Purpose of the research. The purpose of this research paper is to determine the impact of quality management systems used in logistics companies on the competitiveness of the companies. Methodology of the research. A qualitative research of the companies operating in Lithuania was conducted in order to determine what quality management systems are applied in logistics companies. 66 logistics companies working in the field of freight transportation, warehousing, manufacturing and trade were analysed. An interview method was applied for the research, heads of transport departments of the companies were interviewed. The research period was from 2016 to 2018.

Keywords: logistics, competitiveness, logistics processes, quality management.

JEL CODES: E24, L26, O32, O38.

\section{Introduction}

Relevance of the topic. Proper management of the logistics processes promotes the development of various sectors not only at the regional or national level, but at the international level as well. Process optimization and integration of the logistics services in the logistics chain of the company is becoming an integral part of the logistics chain management.

One of the most important current logistics business success guarantors is the quality of the provided services (Chen, Chang, \& Lai, 2009, Huang, Wang, \& Xue, 2012). According to Xie, Wang \& Lai (2011), Rahman (2008), Tapiero \& Kogan (2007), Hays \& Hill (2006), Balachandran \& Radhakrishnan (2005), quality is the basis for the functioning of the service sector, thus one of the main tasks of the rapidly growing service sector is to ensure the quality of service to the customers.

Problem of the research. Service quality is one of the most important aspects of increasing the competitiveness of companies. In order to ensure the quality of the services provided, logistics companies are forced to implement quality management systems.

Copyright (C) 2019 The Authors. Published by Vytautas Magnus University, Lithuanian Institute of Agrarian Economics. This is an open-access article distributed under the terms of the Creative Commons Attribution-NonCommercial 4.0 (CC BY-NC 4.0) license, which permits unrestricted use, distri-bution, and reproduction in any medium, provided the original author and source are credited. The material cannot be used for commercial purposes. 
Whereas logistics companies carry out different activities - from warehousing, marketing, to intermodal and multimodal transportation, there is a risk that inadequate quality management system would result in competitiveness and financial losses.

Purpose of the research. The purpose of the research paper is to determine the impact of quality management systems used in logistics companies on the competitiveness of the companies.

Objectives of the research:

- to review the theoretical aspects of quality management importance in logistics companies,

- to analyse the impact of quality management on the competitiveness in logistics companies,

- to provide an overview of the application of quality management systems in Lithuanian logistics companies.

Methodology of the research. A qualitative research of the companies operating in Lithuania was conducted in order to determine what quality management systems are applied in logistics companies. 66 logistics companies working in the field of freight transportation, warehousing, manufacturing and trade were analysed. For the research an interview method was applied, there were interviewed heads of transport departments of the logistics companies. The research period was from 2016 to 2018.

\section{Competitive Advantage in Logistics}

Activities in any business sector, including logistics activities, are intended to ensure the competitive advantage of the business sector or the entity in the market. It is important to understand what the factors are determining competitive success of the company and which features are the most important to be developed in order to achieve higher economic performance. Knowledge of logistics principles and selfdifferentiation from other organizations engaged in similar activities can provide the organization the competitive advantage (Fugate et al 2010). There are many factors that can determine success in the market, but Christopher (2011) presents three interconnected components that are key to achieving the competitive advantage (Fig. $1)$.

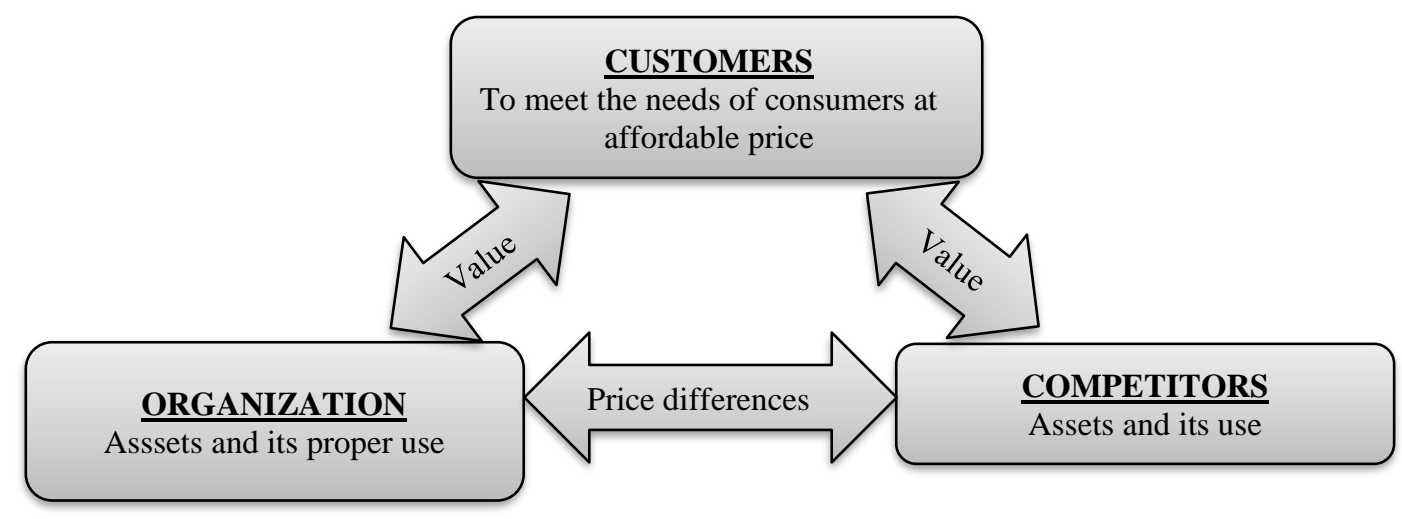

Fig. 1. Competitive Advantage of an Organization (according to Christopher, 2011) 
According to M. Christopher, first of all competitive advantage emerges from the organization's ability to differentiate itself in competitive environment in the eyes of the customer. It is equally important for the organization to offer the lowest price, while earning higher profit. According to the author, success in the market is often achieved by ability to offer better price or greater value. However, if only one of these benefits is offered to the customer, success may not be always guaranteed. The optimum solution is when the company is able to offer the best price to the customer compared to its competitors while delivering a superior (higher quality) product to the customer. One of the main objectives of logistics is precisely to help the organization achieve a balance between price and value advantages, i.e. to offer the customer a better product at a lower price than the competitors (Christopher, 2011).

Better product is a subjective concept. It may include functional, technical and perceived quality, customer expectations and satisfaction. Every customer assesses the quality of a product or a service on the basis of how its expectations and needs are satisfied. Ability to adapt to the dynamics of consumer needs is a guarantor of competitive advantage in today's markets. Coordination of efficiency and flexibility is one of the priority factors in various business sectors (Saruliené, Vilkas, 2011). Flexibility, operational response to changes in customer preferences is particularly important in logistics. Good understanding and knowledge of managing the logistics chain is necessary, because qualitative existence and competitiveness (Lodienè 2012; Matwiejczuk 2013; Pehlivanova 2011; Weijers et al. 2012) as well as successful risk management (Vikulov, Burit, 2014) of the organization depends on quality operation of the elements of its processes.

Optimization of the processes in the logistics chain taking into account creation of the added value, price, quality, customer satisfaction and improvement of efficiency of other factors is one of the key aspects in improving the competitiveness of the business sector or individual business entities, however these processes must be properly analyzed and systematized in order to achieve the overall best result and continuous improvement of the processes of a logistics chain (Lichocik, Sadowski 2013).

Christopher (2011) defines four areas to be addressed in the management of a logistics chain and in order to remain in a competitive environment. These include: responsiveness, reliability, resilience to adapt to a rapidly changing environment and relationships. Fig. 2 shows the correlation between successful management of a logistics chain and customer service elements when seeking for competitive advantage. Quick response to the changing environmental factors, reliable service delivery are key aspects to be taken into account by logistics companies. 


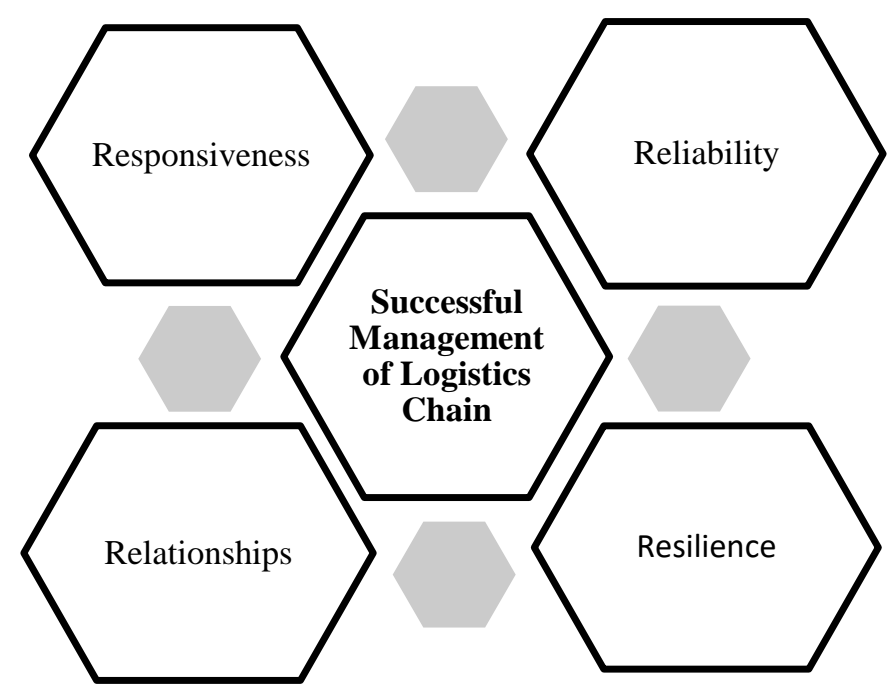

Fig. 2. Logistics Chain Management Areas (according to Christopher, 2011)

According to Christopher (2011), these four areas are the key to achieving the competitive advantage in the market and successfully implementing the goals of an organizations in the field of logistics. When managers focus on these four factors, companies are able to achieve incredibly good results in their activities.

Table 1. Description of Logistics Chain Management Area (Christopher, 2011)

\begin{tabular}{|l|l|}
\hline Management & Description \\
\hline Responsiveness & $\begin{array}{l}\text { In today's rapidly changing environment, it is crucial to be able to respond to the } \\
\text { changing consumer needs as quickly as possible. This must be done not only } \\
\text { within the shortest possible time, it is also very important to be able to make } \\
\text { decisions that are the most in line with consumer expectations. Mobility is the } \\
\text { key. Mobility in the logistics chain will help meet customer demand more } \\
\text { rapidly. Mobility is more important in a rapidly changing market than a long and } \\
\text { consistent planning, because the future picture may not be accurate enough and } \\
\text { therefore detailed planning may become complicated or even risky. In such case } \\
\text { an important role is played by information technology, integration of which in } \\
\text { the company's activities not only helps more efficiently obtain the necessary } \\
\text { information but also to evaluate it, make calculations and take certain actions. }\end{array}$ \\
\hline Reliability & $\begin{array}{l}\text { One of the reasons why companies are keeping a certain amount of inventory is } \\
\text { insecurity. Logistics chain managers may be unsure about the future consumer } \\
\text { demand, performance of the suppliers' obligations to deliver the goods on time } \\
\text { and, ultimately, about the quality of goods or services. One of the key ways to } \\
\text { increase the trust in the logistics chain is to reduce the variety of processes. The } \\
\text { fewer processes are involved in the path of the product from its production to } \\
\text { falling into the hands of consumers, the more efficient may be the management } \\
\text { of the entire logistics chain, thereby reducing uncertainty and mistrust between } \\
\text { those processes. With a smaller number of different processes, it is more difficult }\end{array}$ \\
\hline
\end{tabular}




\begin{tabular}{|c|c|}
\hline & $\begin{array}{l}\text { to administer and control them, which results in mistrust between the participants } \\
\text { in the logistics chain. }\end{array}$ \\
\hline $\begin{array}{l}\text { Resilience to } \\
\text { adapt to a } \\
\text { rapidly } \\
\text { changing } \\
\text { environment }\end{array}$ & $\begin{array}{l}\text { Today's market is volatile: economic and political business environment is } \\
\text { constantly affected by unforeseen crises. Due to these factors logistics processes } \\
\text { become vulnerable increasing the business risk of the organization. Therefore, in } \\
\text { today's economy it is very important not only to minimize the costs and optimize } \\
\text { the processes of operation, but also to be able to respond adequately to constant } \\
\text { changes. }\end{array}$ \\
\hline Relationships & $\begin{array}{l}\text { There is an increasing discussion that customers are seeking to reduce the number } \\
\text { of suppliers and thus simplify the purchase of products. In order to satisfy this } \\
\text { objective, investments must to be made to improve quality, innovations must be } \\
\text { shared, costs must be reduced, and production and movement processes between } \\
\text { the companies must be combined. Close cooperation between organizations is } \\
\text { necessary for this purpose. Organizations are increasingly seeing the benefits of } \\
\text { long-term cooperation. The more processes are combined between raw material } \\
\text { suppliers and end users, the more difficult it is for competitors to penetrate the } \\
\text { market. }\end{array}$ \\
\hline
\end{tabular}

It may propose that that these logistics chain management areas are closely linked to the individual areas of the majority of quality management systems. For example, responsiveness is perfectly illustrated by just-in-time strategy. The just-intime (JIT) strategy is one of the tools to increase the efficiency of a logistics chain, to reduce costs and add value in many organizations. This strategy is used in planning and controlling the processes in order to produce and deliver the products demanded by the customer in the right place, at the right time and only the quantity required by the customer (Hokoma, 2008). According to the author, the purpose of this strategy is to eliminate all possible losses in organizing the logistics of a company. This means by using the JIT strategy all elements that are not creating added value in the logistics process must be eliminated. By applying the JIT strategy, the company must minimize the existing inventory while at the same time creating products or services of the best possible quality. This can be achieved using well-organized networks, producing and transporting appropriate quantities of products demanded by the customer at the right time, providing for long-term cooperation with the sellers of goods or services, reducing the cost of orders, and ordering the required amount of materials, thus avoiding freezing of funds. With the optimum amount of equipment, it is possible to produce a product, but with a limited income, since the company is producing what it will really sell, but it does not prepare for potential demand, which unplanned and unforeseen in advance. Although often the risks arising from this strategy are ignored, the JIT strategy helps meet the needs of consumers with the lowest cost and lowest risk probability (El Dabee, Marian, Amer, 2013).

Lai, Lee (2003) claims that information is the most important JIT strategy. The better the information channels between the company and the suppliers are be developed, the less assets must be held by each company, the storage of which means additional costs. This means that companies and their suppliers must be able to exchange all the necessary information in a timely manner and to promptly process the 
information obtained in order to meet the needs of the customers in a timely manner. Hence, by using the JIT strategy, the company must invest in the introduction of modern software, which would enhance easier exchange and processing of information as well as completion of all the actions in a timely manner.

There are several key principles relevant to implementing the JIT strategy, such as involvement of people, learning and development, sustainable and trust-based relationships with suppliers, elimination of loss-making processes, ongoing work and full quality control (Tourki, 2010). Application of this strategy requires ability to adapt to the changes in demand, to have a good knowledge of the market, which means a lot of emphasis on training and development. It is also important to realize that one person will not be able to properly manage the JIT strategy and meet the needs of consumers, this requires integration of various cooperating groups of employees. Moreover, it is very important to have stable and reliable relationship with suppliers and to work continuously in order to respond to the emerging needs of consumers in a timely manner. Finally, considerable investments in quality are necessary so that after eliminating the loss-making processes, the product of at least the same quality could be supplied (Tourki, 2010).

LEAN system may be applied in the area of reliability. Although there have been claims that this system shall be applied exclusively to production, recently there is an increasing number examples of its application in logistics. The key component in the LEAN philosophy is the constant struggle against waste, which is defined as an activity that does not add any value to the product in the eyes of the consumer, and therefore it needs to be eliminated. The main wastes are as follows:

1. Overproduction: Producing too much or too soon, resulting in poor information flow and excess inventory.

2. Waiting (time on hand): The item/work in the process has stopped, such as machine downtime, bottlenecked operations, equipment changeover, system downtime, system response time, approvals from others, information from customers.

3. Unnecessary transport or conveyance: Movement of work or paperwork from one step in the process.

4. Over processing, or incorrect processing: Applying too much technology or using the wrong tools or procedures in the work process when a simpler and less costly approach may be more effective.

5. Excess inventory: Any supply that is in excess, any form of batch processing, producing more than customer demand.

6. Motion: Movement of people. Reaching for, looking for, or stacking parts, tools, etc. Walking to/ from copier, central filing, fax machine, other offices.

7. Defects: Frequent errors in paperwork, product quality, or delivery performance, leading to excessive cost and decreased customer satisfaction.

8. Unused employee creativity: People 's creativity, ideas, and abilities are not fully tapped. This results in losing ideas, skills, and improvements by not listening to employees. (Wee, $\mathrm{Wu}, 2009$ ). 
Proper selection of the quality management system can significantly improve the quality of the services provided, improve the financial performance of the company and increase its competitiveness in the market.

\section{Impact of Quality Management on Competitiveness}

The need for quality management came as a result of expanding markets and increasing number of competitors, therefore it has become very important to provide the customer with a high-quality product and thus be more competitive than your competitors (Kontautaitè, Zinkevičiūtè 2013). Quality management involves aspects such as occupational safety and environmental protection, focus on the customer and employee health, and observance of the needs of society. In order to remain competitive in the market, logistics companies must apply quality management principles, because this is what their customers and business partners are expecting from them. Satisfaction of customers with the quality of logistics services has a significant impact on the sustainability of enterprises (Lisinska-Kusnierz, Gajewska 2014).

Modern global quality management is an initiative aimed at satisfying the needs of customers, which obliges the organization to continuously improve its activities, involving both the managers and the employees of the company, thus creating a specific organizational culture for quality management. Quality requirement is applied and implemented not only in managing or considering the affairs of the company, it is also related to human resource issues and supply chain management (Mc Carter ir kt. 2005).

Quality system is the ability to deliver products or services meeting consumer and legal requirements, with the aim of fully meeting the needs of consumers (Iden, 2012). The main constraints encountered by most companies using quality management tools and techniques are the lack of knowledge; lack of funds or facilities for training; poor ability of the company to adapt when its employees are not at work due to training purposes (Bamford, Greatbanks 2005).

The majority of scholars in the field of quality management emphasize the importance of analyzing the key component of quality management - satisfaction of consumer needs and exceeding their expectations at the lowest cost - saying that one of the most important requirements of today's market is to be as close as possible to the consumers. Frequently unpredictable behaviour of consumers can disturb even the most thoroughly prepared strategic plans of the company, because consumers are likely to demand a product to fully, i.e. 100 percent, satisfy their needs. The main goal of the quality management is to ensure the required level of quality and maintain it until the consumer is given the expected service or product. The goal is achieved by optimizing the entire service development process according to quality criteria (Serafinas, 2011).

Each author has its own way to interpret the concepts of quality management, however, it is noticeable that in the works the most scholars the concept is considered as the system of constant evolution, development and adaptation to the needs of 
consumers. Concepts of quality management developed by different authors are presented in Table 2 below.

Table 2. Comparison of the Concepts of Quality Management Systems

\begin{tabular}{|c|c|l|}
\hline SOURCE & YEAR & \multicolumn{1}{|c|}{$\begin{array}{c}\text { ASPECTS EMPHASIZED IN THE DEFINITION OF THE } \\
\text { QUALITY MANAGEMENT }\end{array}$} \\
\hline Savsar. M. & 2012 & Improvement of efficiency according to the needs of consumers. \\
\hline Aized T. & 2012 & Continuous improvement of services and processes. \\
\hline Kaziliūnas A. & 2007 & $\begin{array}{l}\text { Continuous improvement of performance in order to maintain the } \\
\text { level of quality. }\end{array}$ \\
\hline $\begin{array}{c}\text { Evans J. } \\
\text { R., Lindsay W. M. }\end{array}$ & 2008 & Transfer from the interest in results to the interest in process. \\
\hline Mikulis J. & 2007 & $\begin{array}{l}\text { Increased performance of the company, improved customer } \\
\text { service, resulting ability to better meet customer needs, } \\
\text { improvement of the competitiveness of the company. }\end{array}$ \\
\hline $\begin{array}{c}\text { Su Mi Dahlgaard- } \\
\text { Park, Jens J. } \\
\text { Dahlgaard }\end{array}$ & 2006 & $\begin{array}{l}\text { Defines the guidelines for continuous improvement of quality } \\
\text { when the company is using tools and methods based on data } \\
\text { collection and analysis. }\end{array}$ \\
\hline $\begin{array}{c}\text { Kazokienė D. } \\
\text { Continuous improvement of the overall performance of the } \\
\text { organization. The main goal is to provide users with high added } \\
\text { value. }\end{array}$ \\
\hline
\end{tabular}

According to Table 1, it can be stated that the key processes characteristic to the quality management mentioned in the definitions of the quality management developed by different authors are development of services and processes, improvement of activities, data collection and analysis. The concept of quality management is characterized by certain similarities. Most of the definitions emphasize continuous development of the company's processes and improvement of its performance, emphasis on the needs of the consumers and the main feature of the quality management - to provide the customers with high added value.

Whereas the application of the quality management in the company is manifested through the prism of process development, it is expedient to analyze the processes, in which the quality management may be applied, and to determine the compatibility of various quality management systems with the processes of the logistics chain of the company. The process is an important component representing how the organization manages and values its customers, i.e. how it creates a competitive potential. Different parameters in each process are presented in terms of this process. Descriptions of the main logistics processes are presented in Table 3 below. 
Table 3. Logistics Processes

\begin{tabular}{|l|l|}
\hline \multicolumn{1}{|c|}{ Process } & \multicolumn{1}{c|}{ Description } \\
\hline $\begin{array}{l}\text { Production } \\
\text { process }\end{array}$ & $\begin{array}{l}\text { Consolidation of the production resources into one combination, allowing to } \\
\text { create a certain product or service (Zinkevičiūte, Vasiliauskas, 2013). }\end{array}$ \\
\hline $\begin{array}{l}\text { Management } \\
\text { system }\end{array}$ & $\begin{array}{l}\text { Internal structure, resource planning system of the company combining all } \\
\text { departments and their functions into a single computer system. The essence of } \\
\text { the entire management system is to combine all divisions of manufacturing or } \\
\text { trading company into one database, which helps to effectively use the internal } \\
\text { structure of the company (Zinkevičiūte, Vasiliauskas, 2013) }\end{array}$ \\
\hline $\begin{array}{l}\text { Production } \\
\text { supply }\end{array}$ & $\begin{array}{l}\text { Search required materials, management of inventory, transportation and } \\
\text { maintenance of proper condition (Zinkevičiūte, Vasiliauskas, 2013). }\end{array}$ \\
\hline $\begin{array}{l}\text { Inventory } \\
\text { management }\end{array}$ & $\begin{array}{l}\text { Inventory shall be understood as a positive factor for maintaining a stable } \\
\text { manufacturing or trading company. Targeted inventory buildup ensures } \\
\text { economies of scale, balance of supply and demand, protects from volatility of } \\
\text { the service (Zinkevičiūte, Vasiliauskas, 2013). }\end{array}$ \\
\hline $\begin{array}{l}\text { Green logistics } \\
\text { Onvironmental and social factors. These types of logistics must be mandatory in } \\
\text { every company concerned about the environmental impact (Sbihi, 2010) }\end{array}$ \\
\hline $\begin{array}{l}\text { Occupational } \\
\text { safety } \\
\text { health policy }\end{array}$ & $\begin{array}{l}\text { Occupational safety and health management system. Companies must seek for } \\
\text { continuous improvement of the efficiency in occupational safety and health } \\
\text { (Zinkevičiūte, Vasiliauskas, 2013). }\end{array}$ \\
\hline
\end{tabular}

Process is the sequence of activities determining the flow of production and service. In developing quality management system for the last few years management an extremely relevant and often analyzed issue. Currently, many companies are faced with the need to reorganize their business processes in order to shorten the time for performance of work, to reduce costs and to improve customer satisfaction. According to G. Knowles (2011), first of all, the process should be planned in order to bring benefit; goals and visions must be grouped in levels of process; process development must be focused on customer needs. This author suggests the following actions to help plan the process:

1) to plan the goals and parameters of the process;

2) to evaluate the positive and the negative factors of the process;

3) arrange the goals of the process;

4) to control the actions.

The first step is aimed at determining which aspects of the process being analyzed are most important. In order to meet the needs of customers, it is important to ensure that the identified aspects are properly controlled, and they deliver the required results. G. Knowles (2011) highlighted the following key aspects of business processes:

- implementation of management systems;

- ability to develop, implement and evaluate the process;

- provision of recommendations for continuous improvement of the quality process.

In order to ensure a stable process, it is necessary to determine whether the results of the process will meet the expectations of the customer. Knowles (2011) says 
that there is one basic method that helps control the process. It is the method of assessing competencies, i.e. it is necessary to determine whether the process is stable and conforms to the specification. If the process is not stable, it will change and will not conform to the desired results. Therefore, quality management systems are implemented in order to ensure stability of the processes. I

According to Hadas et al. (2014), the first quality management system was introduced in 1913. It presupposed the development of other quality management systems. The application and evolution of quality management systems are showed in Fig. 3.

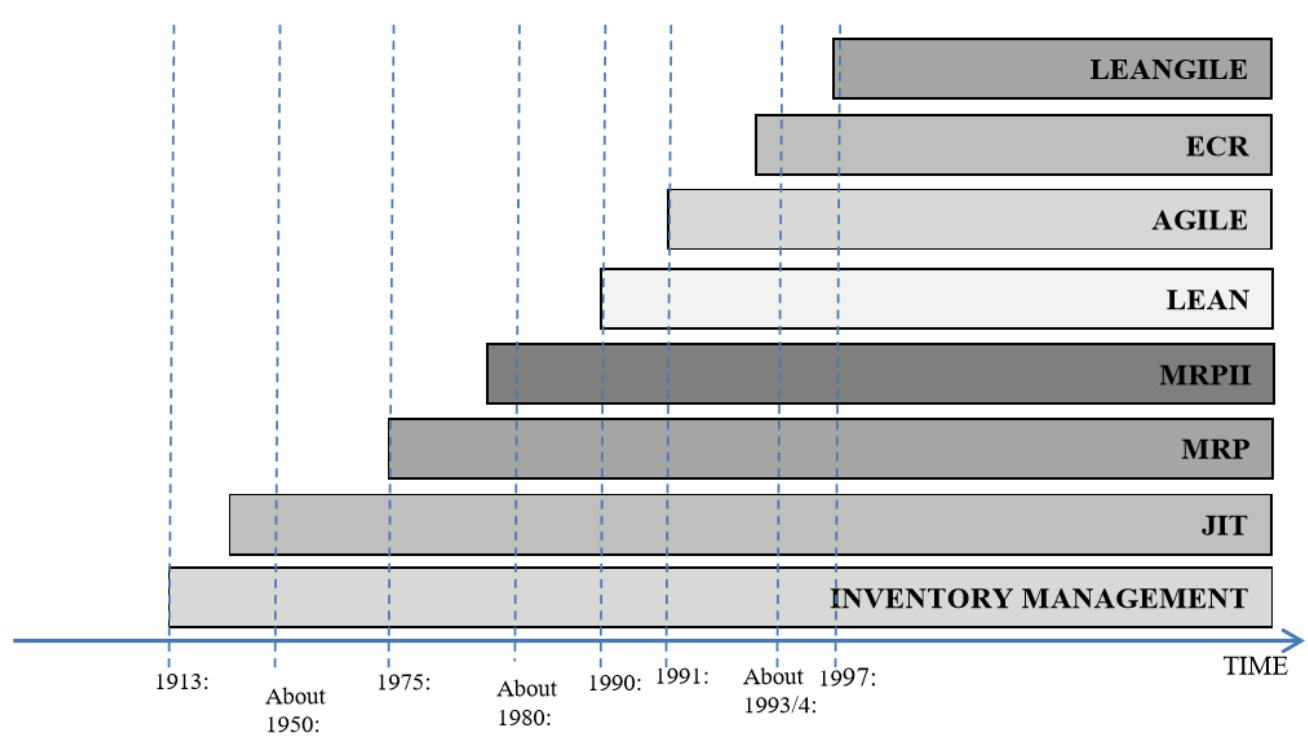

Fig. 3. Implementation and Development of Quality Management Systems (according Hadas et al. 2014)

According to L. Hadas et al. (2014), the origins of the development of quality management systems is Inventory management, which also called the classic strategy. Inventory of the company is a large and expensive investment; therefore better management of the overall stock improves cash circulation and frees the company from high amounts of frozen capital. If the company lacks supplies or parts, the supply process stops. Inventory management basically means a compromise between the surplus and the lack of inventory. If the inventory is too high the company faces direct insurance, tax, storage and moral depreciation costs, as well as the costs of funds frozen in inventory. When there is a lack of inventory, there are problems in meeting the demand, the level of customer service may decrease, and the risk of loss in sales increases. The following inventory management methods may be distinguished:

- Two Box System. When the first box is empty, the company places second order. The amount of inventory in the second box indicates the amount of inventory required until the order is executed.

- Fixed Interval Model. When using the fixed interval model, the inventory is ordered in fixed or regular intervals. 
- $\mathrm{ABC}(\mathrm{D})$ Classification Method. The inventory is classified into 3(4) groups. The most important inventory is classified in Group A, accordingly less important inventory is attributed to Group B and C.

- Group D is for the inventories, which are economically "dead", i.e. they cannot be sold by one.

- 80/20 Rule. The majority of sales (revenue) comes from a relatively small part of the range, i.e. about 80 percent of the income is derived from $\sim 20$ percent of the assortment.

- Economic Order Quantity (EOQ) Model. Based on the estimated costs, the most economical amount of inventory needed on stock or to be ordered is determined (Stungienè. 2010; Adomėnas (2011).

Inventory management methods provided the foundation for the quality management systems, such as ISO 9001, ISO 14001, OHSAS 18001, Lean, Six sigma, etc.

A qualitative research of the companies operating in Lithuania was conducted in order to determine what quality management systems are applied in logistics companies. The research was conducted in 2016 - 2017. 66 logistics companies working in the field of freight transportation, warehousing, manufacturing and trade were analyzed. An interview method was applied for the research, heads of transport departments of the companies were interviewed. The researched showed that the majority of companies have implemented ISO quality management systems (Fig. 4).

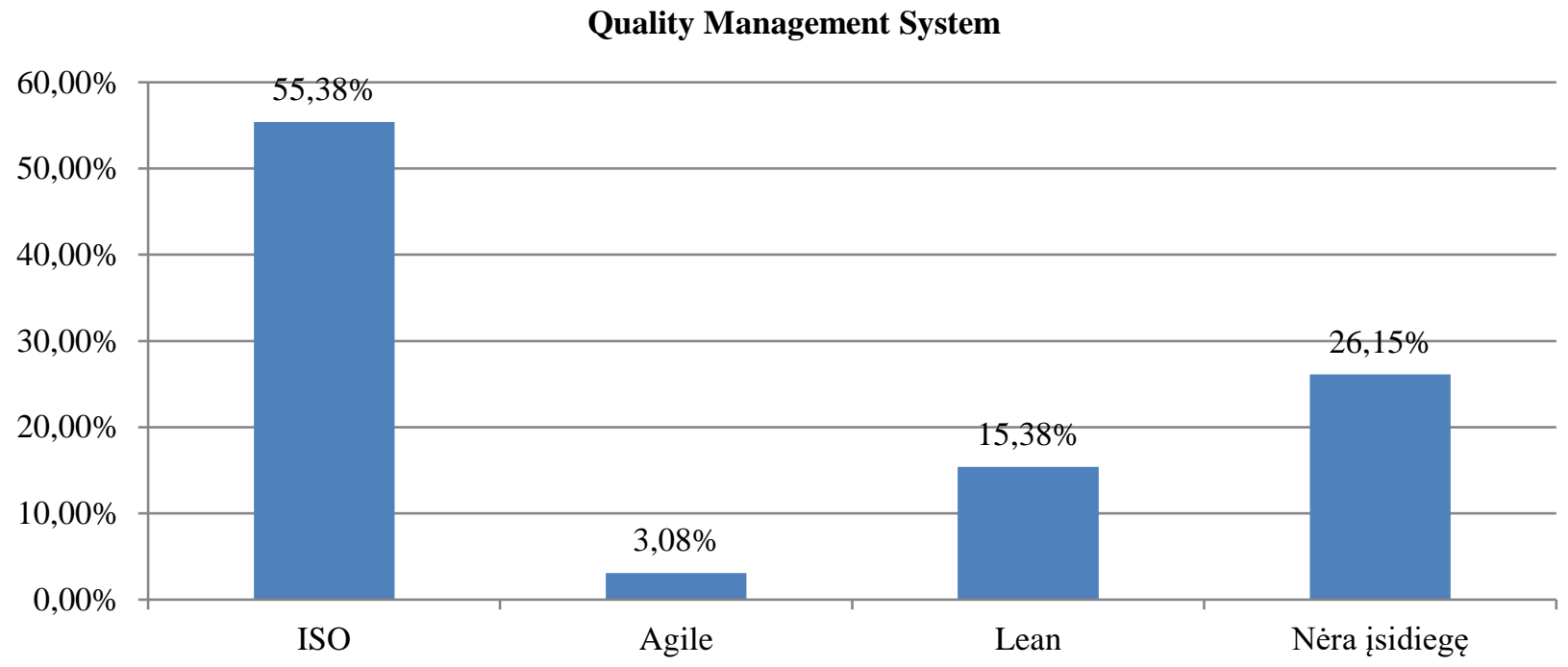

Fig. 4. Quality Management Systems in Lithuanian Logistics Companies

The second most popular quality management system is LEAN, slightly more than 3 percent of the companies interviewed are using the Agile system. Nearly one third of the analyzed logistics companies have not implemented any quality management system. 
In analyzing the impact of the quality management systems on the competitiveness of logistics companies, companies implementing the ISO standards, LEAN system and companies which are not using any quality management system were chosen. The heads of the companies were asked to identify the main problems in organizing the logistics processes of the companies (Table 3) and to evaluate the relevance of the problems using a 5 point Likert scale, in which the most common problems were evaluated by 5 points, the least common by 1 point and rare problems - by 0 points. The results are shown in Table 4.

Table 4. Errors in Logistics Processes

\begin{tabular}{|l|c|c|c|}
\hline \multicolumn{1}{|c|}{ PROCESS } & ISO & LEAN & NO QUALITY MANAGEMENT SYSTEM \\
\hline Management System & $\mathbf{5}$ & 4 & $\mathbf{5}$ \\
\hline Customer Service & 4 & 1 & 4 \\
\hline Production supply & 3 & 2 & 1 \\
\hline Inventory Management & 1 & $\mathbf{5}$ & 2 \\
\hline Warehousing & 2 & 3 & 3 \\
\hline
\end{tabular}

The research revealed that quality management systems have no impact on the management processes of the companies. If appropriate asset utilization and customer satisfaction (according to Christopher, 2011) is considered as the tool for improvement of the competitiveness of the logistics companies, the standards of ISO Group have no significant relevance to the improvement of competitiveness. Logistics companies implementing these quality management systems face similar problems as the companies that do not implement any quality management systems, i.e. customer service quality problems, warehouse management mistakes. According to the research carried out, LEAN system, the basis of which in the analyzed case is proper utilization of assets to achieve the quality of customer service, may be applicable to improvement of competitiveness.

\section{Conclusions}

First of all competitive advantage emerges from the ability of an organization to differentiate itself in competitive environment in the eyes of the customer. It is equally important for the organization to offer the lowest price, while earning higher profit. Optimization of the processes in the logistics chain taking into account creation of the added value, price, quality, customer satisfaction and improvement of efficiency of other factors is one of the key aspects in improving the competitiveness of the business sector or individual business entities in the market.

Quality management involves aspects such as occupational safety and environmental protection, focus on the customer and employee health, and observance of the needs of society. In order to remain competitive in the market, logistics companies must apply quality management principles, because this is what their customers and business partners are expecting from them. The research has proven that 
the areas of logistics chain management are closely linked to the individual areas of the majority of quality management systems.

The research revealed that practically quality management systems do not have any effect on company management process. Logistics companies implementing ISO quality management systems are facing similar problems as companies that do not implement any quality management systems: i.e. customer service quality problems, warehouse management mistakes. According to the research carried out, LEAN system, the basis of which in the analyzed case is proper utilization of the assets to achieve the quality of customer service, may be applicable to improvement of competitiveness.

\section{References}

Adomėnas, V. (2011). Standartizuota vadybos sistema: nuo kūrimo iki tobulinimo. Kaunas: Kauno technologijos universitetas.

Aized T.Total Quality management and Six sigma. Croatia, 2012

Balachandran, K. R., \& Radhakrishnan, S. (2005). Quality implications of warranties in a supply chain. Management Science, 51 (8), 1266- 1277. http://dx.doi.org/10.1287/mnsc.1050.0408

Bamford, D. R.; Greatbanks, R. W. 2005. The use of quality management tools and techniques: a study of application in everyday situations, International Journal of Quality \& Reliability Management 22(4): 376-392. http://dx.doi.org/10.1108/02656710510591219

Chen, K., Chang, C., \& Lai, C. (2009). Service quality gaps of business customers in the shipping industry. Transportation Research Part E, 45, 222-237. http://dx.doi.org/10.1016/j.tre.2008.02.005

Christopher M. (2011). Logistics and Supply Chain Management (4th Edition)

Dahlgaard Jens J., Su Mi Dahlgaard-Park, (2006) "Lean production, six sigma quality, TQM and company culture", The TQM Magazine, Vol. 18 Issue: 3, pp.263-281, https://doi.org/10.1108/09544780610659998

El Dabee, F., Marian, R. \& Amer, Y. (2013) An Optimisation Model for a Simultaneous CostRisk Reduction in Just-in-Time Systems, Australian Journal of Multi-Disciplinary Engineering, 9:2, 139-147

Evans J. R., Lindsay W. M. The Management and Control of Quality. Stantonbury, 2008.

Fugate, B., S., Mentzer, J. T., Stank, T., P., 2011, Logistics Performance: Efficiency, Effectiveness and Differentiation, Journal of Business Logistics, vol. 31, no. 1 :43-62. Prieiga per internetą: Wiley online library.

Hadas, L., Stachowiak, A., Cyplik, P. (2014). Production-logistic system in the aspect of strategies for production planning and control and for logistic customer service. LogForum.

Hays, J., M., \& Hill, A., V. (2006). Service guarantee strength: the key to service quality. Journal of Operations Management, 24 (6), 753-764. http://dx.doi.org/10.1016/j.jom.2005.08.003

Huang, B., Wang, T., \& Xue, X. (2012) Service-selecting approach based on domainspecified 'Quality of Service' model and its application in logistics. The Service Industries Journal, 32 (9), 1571-1588. http://dx.doi.org/10.1080/02642069.2010.551761.

Iden, J. 2012. Investigating process management in firms with quality systems: a multi-case study, Business Process Management Journal 18(1): 104-121.

Hokoma, R. A., Khan, K. M., Hussain, K. (2008) "Investigation into the implementation stages of manufacturing and quality techniques and philosophies within the Libyan cement industry", Journal of Manufacturing Technology Management, Vol. 19 Issue: 7, pp.893-907, https://doi.org/10.1108/17410380810898804

Kaziliūnas A. Kokybės vadyba. Vilnius, 2007 


\section{Audrius Gargasas, Mindaugas Samuolaitis, Indra Mūgienè. Quality \\ Management Systems in Logistics}

Kazokienė D. KVS - Vartotojui ir verslui. Kokybės vadybos iššūkiai: Vertè vartotojui ar nauda verslui.// Tarptautinės kokybės vadybos konferencijos pranešimų medžiaga. Kaunas, 2006. P. $61-65$

Knowles, G. (2011) Quality management. Graeme Knowles and Ventus Publishing ApS Free ebook online at www.bookboon.com

Kontautaitè, D.; Zinkevičiūtė, V. 2013. Ekspedicinių įmonių veiklos kokybės gerinimo poreikis ir galimybès, Mokslas - Lietuvos ateitis [Science - future of Lithuania]: Verslas XXI amžiuje [Business in XXI Century] 5(1): 22-28.

Lai, C. L.; Lee, W. B. (2003) A study of system dynamics in just-in-time logistics. Iš Journal of Materials Processing Technology. [interaktyvus]. No. 138 p. 265-269. Prieiga per internetą: http://ac.els-cdn.com/S0924013603000839/1-s2.0-S0924013603000839-main.pdf?_tid=036f4ca47d26-11e3-9b96.

Lichocik G., Sadowski A., 2013, Efficiency of supply chain management. Strategic and operational approach. Scientific Journal of Logistics. LogForum 9 (2), p. 119-125. ISSN 1895-2038.

Lisinska-kusnierz, M., Gajewska, M., (2014). Customer satisfaction with the quality of the logistic services. Scientific Journal of Logistic. LogForum 10 (1), p. 13-19. ISSN 1895-2038.

Lodienè, d., (2012) Globalios tiekimo grandinès itaka verslo organizacijai. Vadybos mokslas ir studijos- kaimo verslų ir jų infrastruktūrai 3 (32). Mokslo darbai. p. 98-105. ISSN 1822-676.

Matwiejczuk, R., (2013). Logistic potentials in business competitive advantage creation. Scientific Journal of Logistic. LogForum 9 (4), p. 265-275. ISSN 1895-2038.

McCarter, M. W.; Fawcett, S. E.; Magnan, G. M. 2005. The effect of people on the supply chain world: some overlooked issues, Human Systems Management 24(3): 197-208.

Mikulis J. Pažangūs vadybos principai. Visuotinès kokybės vadyba. Vilnius, 2007

Pehlivanova, T., (2011). Optimization of management of logistic systems in agriculture. Trakia Journal of Sciences, Vol. 9, No 4, p. 16-19. ISSN 1313-7069.

Rahman, S., U. (2008) Quality management in logistics services: A comparison of practices between manufacturing companies and logistics firms in Australia. Total Quality Management \& Business Excellence, 19 (5), 535-550. http://dx.doi.org/10.1080/14783360802018202

Sarulienè, A., Vilkas, M., (2011). Efektyvumo ir lankstumo suderinimas tiekimo grandinèje. Ekonomika ir vadyba. P. 907-915. ISSN 1822-6515.

Savsar. M. Quality Assurance and Management. 2012

Serafinas D., Kokybės vadybos teorijos praktinis taikymas, 2011

Sbihi, A, W. Eglese, R. W., (2010)/ Combinatorial optimization and Green Logistics. Annals of Operations Research March 2010, Volume 175, Issue 1, pp 159-175

Stungienè S. Operacijų valdymas. 2010

Tapiero, C., S. \& Kogan, K. (2007). Risk and quality control in a supply chain: competitive and collaborative approaches. Journal of the Operational Research Society, 58 (11), 1440-1448. http://dx.doi.org/10.1057/palgrave.jors.2602420

Tourki, T. (2010) Implementation of Lean within the Cement Industry. [interaktyvus]. Leicester: De Montfort University, Prieiga per internetą: https://www.dora.dmu.ac.uk/bitstream/handle/2086/4577/PhDThesis_TaherTourki.pdf?sequence=1.

Vikulov, V., Burit, A., (2014). Risk assessment and management logistics chains. Scientific Journal of Logistic. LogForum 10 (1), p. 43-49. ISSN 1895-2038.

Weijers, S., Glockner, H., Pieters, R., (2012). Logistic service providers and sustainable physical distribution. Scientific Journal of Logistic. LogForum 8 (2), p. 157-165. ISSN 1895-2038.

Wee, H.M., Wu, S., (2019). „Lean supply chain and its effect on product cost and quality: a case study on Ford Motor Company". Supply Chain Management: An International Journal, Volume 14 Number 5, 2009. 
Xie, G., Wang, S. Y., \& Lai, K. K. (2011). Quality improvement in competing supply chains. International Journal of Production Economics, $134 \quad$ (1), 262-270. http://dx.doi.org/10.1016/j.ijpe.2011.07.007

Zinkevičiūtè, V., Vasiliauskas, A., V. (2013). Gamybos logistika. Gamybos vadyba. Klaipèda.

\section{KOKYBE்S VADYBOS SISTEMOS LOGISTIKOJE \\ *Audrius Gargasas¹, Mindaugas Samuolaitis ${ }^{2}$, Indra Mūgienè ${ }^{3}$ \\ 1,2,3, Vytauto Didžiojo universitetas}

Received 0515 2019; accepted 30062019

Paslaugu kokybė yra vienas iš svarbiausių įmonių konkurencingumo didinimo aspektų. Logistikos įmonès ịgyvendina kokybės valdymo sistemas, kad užtikrintų paslaugų kokybę. Kadangi logistikos įmonès vykdo ịvairią veiklą, kyla pavojus, kad netinkamos kokybės valdymo sistemos taikymas gali sukeltų finansinių nuostolių. Šio darbo tikslas - nustatyti logistikos ịmonèse naudojamų kokybės vadybos sistemu įtaką i̇monių konkurencingumui. Buvo atliktas kokybiškas Lietuvoje veikiančiu imonių tyrimas siekiant nustatyti, kokias kokybès valdymo sistemas taiko logistikos įmonèse. Išanalizuotos 66 logistikos įmonès, dirbančios krovinių gabenimo, sandèliavimo, gamybos ir prekybos srityje. Tyrimui buvo taikomas interviu metodas, apklausti imonių transporto skyrių vadovai. Tyrimo laikotarpis buvo nuo 2016 iki $2018 \mathrm{~m}$.

Raktiniai žodžiai: logistika, konkurencingumas, logistikos procesai, kokybès valdymas. JEL kodai: E24, L26, O32, O38. 